УДК 811.163.41(497.15)'282.2

https://doi.org/10.18485/msc50.2021.2.ch26

Слободан Реметић

\title{
О ЈОШ ЈЕДНОМ НЕЗАПАЖЕНОМ ЕКАВСКО-ЈЕКАВСКОМ БОСАНСКОМ ГОВОРУ
}

Наша научна јавност била је не мало изненађена Ружичићевим открићем тешањско-маглајског екавско-јекавског говора. ${ }^{1}$ Истина, још је Решетар почетком овога вијека на разним тачкама Босне код Муслимана слушао екавске облике. ${ }^{2}$ Појавила су се различита тумачења те појаве, као и поријекла самог тешањско-маглајског говорног типа. То питање је прилично осјетљиво и важно јер неминовно задире у проблем језичке прошлости међурјечја Босне и Дрине, за које су неки наши еминентни дијалектолози сматрали да је било икавско, а да је данашња слика - резултат мијешања домаће икавштине и са југа приспјеле ијекавске компоненте. Ипак, резултати послијератних теренских истраживања ${ }^{3}$ на-

${ }^{1}$ Гојко Ружичић, Један незапажен босански говор. - Прилози за књижевност, језик, историју и фолклор, књ. XVI, св. 2, Београд 1936, 236-254.

${ }^{2}$ Milan Rešetar, Der stokavische Dialekt. - Kaiserliche Akademie der Wissenschaften, Schriften der Balkankommission, VIII, Wien 1907, 72-73.

3 Уп. поред. Ружичићевог рада и: Ivan Brabec, Rad na ispitivanju govora tuzlanske oblasti. 1951. god. - Ljetopis JAZU 59, Zagreb 1954, 173-174; Ivan Brabec, Govor Tuzle i okolice. Докторска дисертација у рукопису, Загреб, 1955 (Свеучилишна библиотека), стр. 223 + 2 дијал. карте; Ivan Brabec, Glavnije fonetske osobine govora u tuzlanskom kraju (upoređene sa osobinama u drugim štokavskim govorima). - Pitanja književnosti i jezika, knj. IV i V, sv. b, Sarajevo 1957-58, 43-68; Dalibor Brozović, Izvještaj o istraživanju govora u dolini rijeke Fojnice. - Ljetopis JAZU 62, Zagreb 1957, 375-380 + дијал. карта; Dalibor Brozović, Izvještaj o dijalektološkim istraživanjima u dolini rijeke Fojnice (nastavak). - Ljetopis JAZU 63, Zagreb 1959, 431-438; Dalibor Brozović, Govor u dolini rijeke Fojnice. Докторска дисертација у рукопису, Загреб (Архив Филозофског факултета у Загребу), стр. XXXV + 1-220 + XXXVI-XLVII + дијал. карта; Dalibor Brozović, Dijalektološka istraživanja u Bosni (okolica Livna i visočki kraj). - Ljetopis JAZU 64, Zagreb 1960, 347-351; Dalibor Brozović, Izvještaj 
веденог подручја недвосмислено иду у прилог теорији о аутохтоном, самосталном развоју источнобосанске шћакавске ијекавштине. ${ }^{4}$ Они, као и резултати најновијих испитивања западносрбијанских говора, ${ }^{5}$

o dijalektološkim istraživanjima u srednjoj Bosni (okolica Kraljeve Sutjeske i Vareša $i$ lijeva obala Krivaje). - Ljetopis JAZU 65, Zagreb 1961, 334-351; Dalibor Brozović, O problemu ijekavskošćakavskog (istočnobosanskog) dijalekta. - Hrvatski dijalektološki zbornik, knj. II, Zagreb 1966, 119-208; Jovan Vuković, Kreševsko-lepenički govor. Posebna izdanja Naučnog društva SR BiH, knj. III, Sarajevo 1963, 287-310; Jovan Vuković, Govorne osobine (Žepe). - Glasnik Zemaljskog muzeja u Sarajevu, Etnologija, n. s., sv. XIX, Sarajevo 1964, 46-52; Jovan Vuković, Bosanski i hercegovački ijekavski tipovi (u svetlu raščlanjivanja ijekavskog narečja). - Glasnik Zemaljskog muzeja u Sarajevu, Etnologija, n. s., sv. XVIII, Sarajevo 1963, 17-28; Mijo Žuljić, Današnji vareški dijalekat. - Školski vjesnik, Sarajevo 1908, 36-41; 148-151, 255-258, 347-351, 425-428, 495-499, 572-575, 669-672, 773-777, 894-908; Herta Kuna, Povodom izvještaja Slavka Pavešića o proučavanju govora u selima Očeviji i Vijaci u Bosni. - Filologija 6, Zagreb 1970, 357-358; Miloš Okuka, Neke osobenosti vokalizma današnjeg govora donjeg toka Usore. - Radovi Filozofskog fakulteta u Sarajevu, knj. VII, Sarajevo 1972-73, 83-100; Miloš Okuka, Dijalektološki tekstovi iz donjeg toka Usore. - ЗФЛ XVI/2, Нови Сад 1973, 207-213; Slavko Pavešić, O narodnom govoru u Lepenici u Bosni. - Ljetopis JAZU 64, Zagreb 1960, 362-393 + дијал. карта; Slavko Pavešić, Izvještaj o proučavanju govora u selu Očeviji $i$ Vijaci u Bosni. - Ljetopis JAZU 67, Zagreb 1963, 298-304; Božidar Finka i Slavko Pavešić, Izvještaj o istraživanju govora u području između planine Zvijezde i rijeke Krivaje u Bosni. - Ljetopis JAZU 68, Zagreb 1963, 291; Слободан Н. Реметић. Фонетске и морфолошке карактеристике говора Срба у Кладюу и околини. - Прилози проучавању језика (издаје Катедра за јужнословенске језике Филозофског факултета у Новом Саду) књ. VI, Нови Сад 1970, 105-133; Милорад Симић, Говор села Обади у босанском Подриюу. - СДЗб XXIV, Београд 1978, 1-124; Dragomir Vujičić, Prilog proučavanju govora Donjeg Birča. - Radovi ANUBiH, knj. LXX, Odjeljenje društvenih nauka, knj. 21, Sarajevo 1981, 195-210; Слободан Реметић, Судбина прилога времена прошлог у иентралним дијалектима српскохрватског језика (с освртом на ситуацију у једном источнобосанском говору). - Научни састанак слависта у Вукове дане, књ. 7, св. 1, Београд 1981, 71-78; Слободан Реметић, Конструкиија типа шт а чине с оне ђеце у говорима источне Босне. - JФ XXXVII, 1981, 265-272.

${ }^{4}$ Up. D. Brozović, O problemu ijekavskošćakavskog (istočnobosanskog) dijalekta. Hrvatski dijalektološki zbornik II, Zagreb 1966, 119-208; Dalibor Brozović, O jednom problemu naše historijske dijalektologije - stara ikavsko-ijekavska granica. - Зборник за филологију и лингвистику IV-V, Нови Сад 1961, 51-57; Др Павле Ивић, Дијалектологија српскохрватског језика. Увод и итокавско наречје. - Нови Сад (Матица српска) 1956, 145.

${ }_{5}^{5}$ Уп. Слободан Реметић, О незамененом јату и икавизмима у говорима северозападне Србије. - Српски дијалектолошки зборник XXVII, Београд 1981, 9-105; Радоје Симић, Скица за дијалектолочку карту северне Србије. - Југосло- 
остављају без ваљанијих аргумената и адута мишљења да је простор између Босне и Дрине био расадник икавштине која ће се проширити и на сусједне крајеве, гдје ће пред налетом екаваца оставити трагове у тзв. „икавизмима” шумадијско-војвођанског дијелакта, а неће боље проћи ни на сопственом огњишту, гдје ће је, опет, преплавити ијекавски досељеници.

Превасходни задатак овога прилога је да скрене пажњу на чињеницу да се тешањско-маглајска судбина јата може срести и у другим крајевима Босне. О чему се заправо ради?

Већ готово пуних тридесет година слушам код кладањских Муслимана (првенствено код дјеце) екавски изговор у низу лексема, о чему сам прије десетак година успутно и писао, ${ }^{6}$ а за косовско-ресавске ликове не́caм, не́си итд. изнио претпоставку да су их „можда донијели муслимани исељеници из Србије у прошлом вијеку." Скупљајући, међутим, прошле године у Кладњу грађу за Босанско-хериеговачки дијалектолошки атлас, одмах сам сагледао суштину проблема и суочио се са крупним и надасве интересантним потешкоћама. Кладањска дјеца, радници, па и нижи службеници, дакле прије свега млађи свијет, на мјесту дугога јата готово непогрешиво изговарају дуго е (се̂но, мле́ко, иеёй, онесвёстй се), док су код кратког јата типични јекавци. На другој страни, међу првим, вјеродостојним носиоцима дијалекта, значи међу најстаријим становницима, рођеним у овој босанској варошици, рјеђе ће се чути примјери типа се̂но, те́no, сне̂́. Да ствар буде интересантнија, писменији кладањски „екавци” су свјесни свога изговора и никад се нико од њих неће преварити нити ће дозволити да га неко „наведе” да каже дѐиа, лёто, пёсма. Исто тако, они су убијеђени да је тај њихов специфични екавизам импортован из Србије у вријеме сеоба послије ослободилачких ратова на тој страни (знају да има досељеника „от Колобаре”, Ваљева, Ужица). Испоставило се да су у праву када су ме увјеравали да тако говоре и на Плаховићима, мусли-

венски семинар за стране слависте, књ. 31, Београд 1980, 93-136; Мр Слободан Реметић, Питане икавизама шумадијско-војвођанског дијалекта у свјетлу потврде фонолошког јата у нижим србијанским говорима. - Научни састанак слависта у Вукове дане, књ. 10, св. 1, Београд 1981, 103-108.

${ }^{6}$ Слободан Н. Реметић, Фонетске и морфолошке карактеристике говора Срба у Кладюу и околини, 108.

7 Слободан Н. Реметић, Фонетске и морфолошке карактеристике говора Срба у Кладюу и околини, 111. 
манском селу од 60-ак домова, од Кладња удаљеном око три километра. Пошао сам тамо и брзо се увјерио да је судбина јата бе зм а ло и ден т ична оној у Тешњу и Маглају. Основни рефлекс дугог јата је ё: бе́да, бе́ло, бле́да, бе́сни, бреег, Бре́зоюа, бреิст, ӱвёк, ве́нии, увре́дили, вре́ђала, вре́ме, погре́шили, оде́ло, де́лили, де́те, Ждре́ла (топ.), зве́зда, лерво, ле́ћили

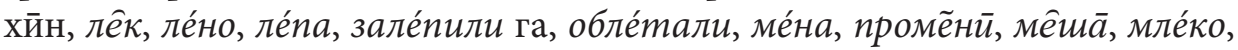
Не́мии, пе́сак, пле́нђија, на̀прёд, ре́тко, ре́ка, рёћи, ре́шили, сеิно, се́ии, по све́ту, све́ћу, сме́шно, сне̂г, сре́да, сте́на, стре́ла, теєсто, потре́били, тре́зан, процегедй (през.), иеевви, ире̂п и сл.

На другој страни кратко јат има јекавски рефлекс: бјёжи, бјелиेиа, Бјѐлава, вјёшт, вјётар, вјёштииа, дуговвећан, вјѐнћали се, вјёра, дјѐма (двјема), двјёста, дјѐвојка, дјёверр, дјёд, дјѐиа, љепо̀та, љеӥшй, мјёра, мјёсећина, пјёсна, пјёна, сјѐтлииа, сјёдок, сјёме, сјёвер, сјёли, сјёме, тјёме, тјемѐнаћа, ијёпта и сл.

Према тешањско-маглајском двй и прйје овамо је двйје и прӥје. Наведене изузетке треба посебно посматрати јер су у питању једини примјери са дугим јатом на отвореној ултими. Овдје наводим још и податак да се секвенце $\bar{u} р$ и йр и у Плаховићима владају као код Ружичића: верр, жерр, ме̂р, приме́ри, ме́рђија, водерр, де́рали; вјёрови, мјерно̀ћа, сјеро̀тињь, оба̀зјере̄ ce, cànjēpe.

Друга важна одлика нашега говора јесте врло жива употреба метатонијског акута, за који су и неки други истраживачи међурјечја Босне и Дрине навели потврде, али некако оскудно и на начин који је читаоца остављао у недоумици а не ријетко изазивао невјерицу и сумњу у ваљаност презентираног материјала.

Пошто о карактеристикама плаховићког говора детаљније пишем на другом мјесту, овдје ћу у границама расположивог времена и простора скренути пажњу на још неке његове важније црте.

1. У вези са вокализмом наводим облике дйждень $\bar{\kappa}$, мйњье и дйљье, лик грёблье (али је у̀крали, нара́сло, вра́баи) и податак да је прилично изражена редукција ненаглашених вокала, поготово у случајевима гдје је потпомогнута морфолошким моментима (дрвѐнна, матрѝја̄л, сто̀лца, двӧј, трӧј, зӓјно, зӓјнићкй, ни́су вйли „видјели”, нару́хће ме „наружиће ме", Са̀ра̄jвo).

2. Инвентар прозодема обухвата пет акцената $(\hat{\mathrm{V}}, \tilde{\mathrm{V}}, \hat{\mathrm{V}}, \mathrm{V}, \grave{\mathrm{V}})$, као и неакцентовану дужину и краткоћу. У вези са њиховом дистрибуцијом пажње су вриједни сљедећи моменти:

a) може стајати на сваком слогу у ријечи: (љуิди, зафркаิје̄, жене, дебљине), с тим да ће се наћи и потврде спорадичног новошто-

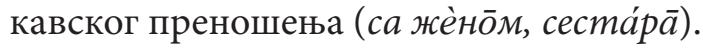


б) ' и ' могу стајати на сваком слогу осим задњега, а " по правилу само на првом. Изузетак чине позајмљенице из других језика (Карӓула, командӓнт, специјалйста, интересӓнтно, Арнӓутовић), специфични случајеви типа огрӓишее, једвӓ, тамӓм, енодӧл, евогӧр и сл. и у, из сусједних мјеста унијетим, облицима са ијекавским рефлексом јата (умрйјет // умретm, нанӥјет, замйјесиммо, одадрйјет).

в) Дистрибуција је у начелу слободна. Он се јавља и на иницијалним, и на медијалним, и на финалним слоговима, отвореним и затвореним, а такође и на једносложницама. Ипак његова фреквенција у финалним слоговима, укључујући ту и једносложне ријечи, мање је висока него у другим положајима: они се

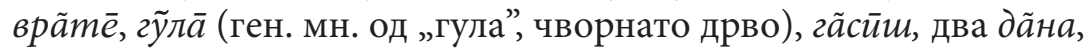

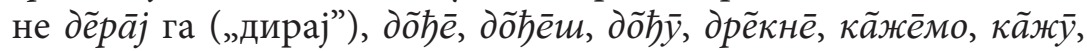

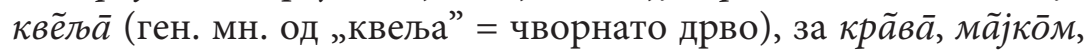

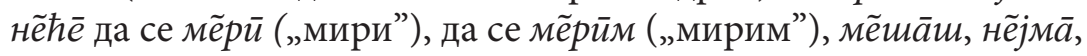

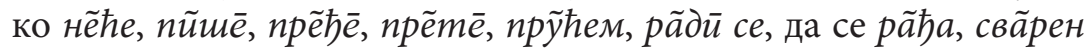

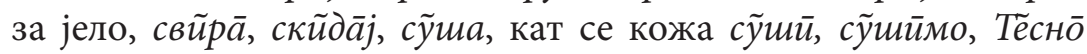

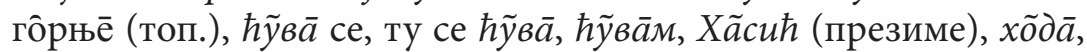

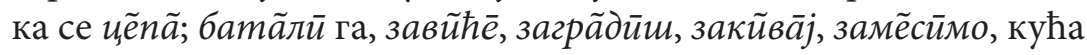

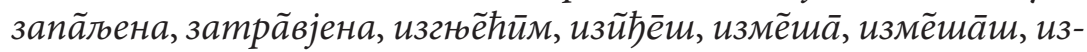

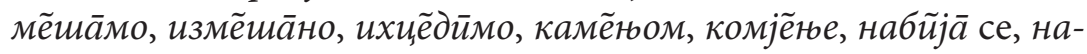

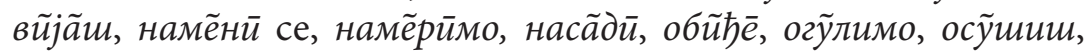

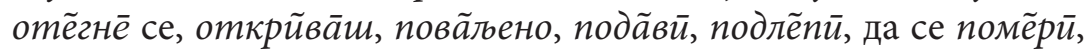

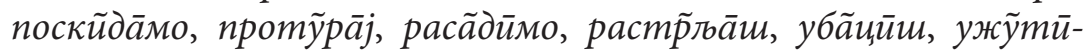

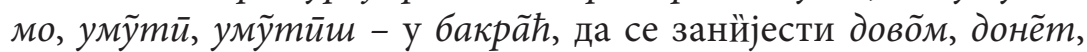

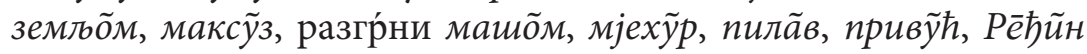

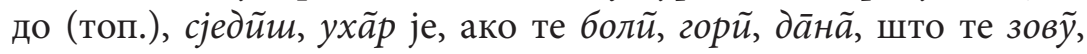

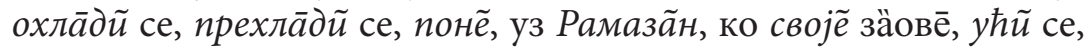
сми̃ се, сйд и сл.

г) Ненаглашена дужина се добро чува, с тим да се овдје може

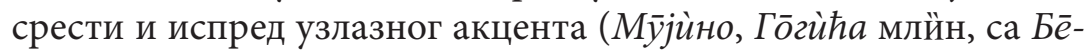

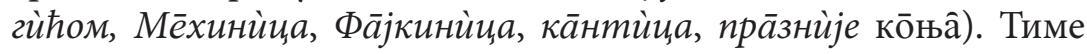
се дошло до могућности да једна ријеч са узлазним акцентом може имати и предакценатску и послијеакценатску ненаглашену дужину (Мёхинйц,, мȳjùне̄ крӓвё).

д) Изостаје дужење вокала испред секвенце сонант + консонант (сйнце, на̀ суниу, слӓмка, овиз, клйнцом, мо̀мка, гӱбавиц, ко̀мшинка, цийганка), а уочљива је и тенденција скраћивања дугог $p$

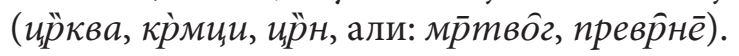


3. Код консонантизма ћемо се задржати на свега неколико појединости:

а) Говор не зна за африкате ч и и (мӓћка, ћвѐла, пёнђер, сӓђа̄к, ђӓб-ђабу̀не).

б) Готово да нема секвенце $\bar{u}+$ консонант (клӥвко, шйвка, кӧвћа,

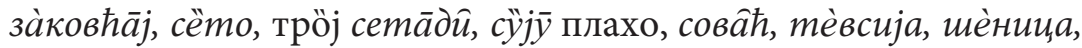

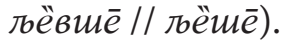

в) Секвенце $\partial н$ и дю упрошћене су редукцијом опструента или, пак, геминацијом назала (по̄не̂// по̄не̃, јѐна, пӧница, гла́на, хлӓне сер „хладне се”, на̀ ну „на дну”, дӓни хйн „им”, зӓнье, у ба̀њьy „у

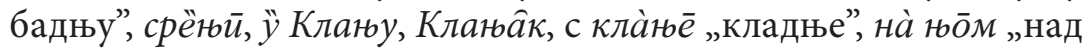
њом"; гла́нна, јѐнно). На сличном принципу дошло је и до ликова сѐлло, осѐллај ко̀ња, двйје по̀ланице „подланице”.

г) Етимолошко $x$ се чува у свим положајима, изузимајући ултиму, гдје му је изговор у случајевима у којима је саставни дио ос-

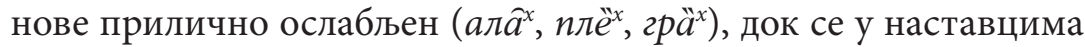
углавном и не чује (дóђо, нӓшије // нӓшијен). С друге стране, тај „губитак” је богато компензиран секундарним $x$ добијеним:

- елиминисањем вокалног $p$ на почетку слога ( $x \grave{p} ђ a, x \grave{p} в е$ се,

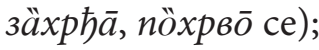

- све експанзивнијом тенденцијом уклањања иницијалног во-

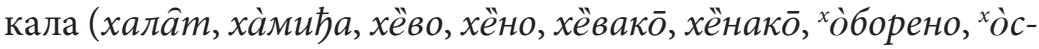

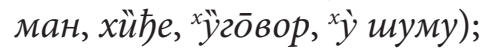

- спорадичним случајевима протетичког $x$ испред иницијалног сонанта $р$ и л: хрӥпа, хрѐna, хро̀са, хло́nов, хлӧnта, на

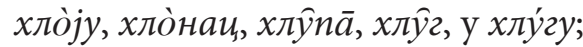

- уклањањем секвенци -си- и -шћ- (ко̀хии, ихива̀ло се, ихиегед

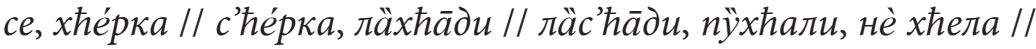

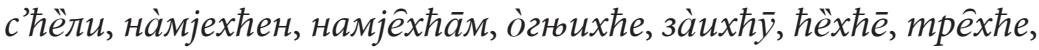
нару́xће ме (слично стање је примећено у говору Муслимана код Сјенице $\left.{ }^{8}\right)$;

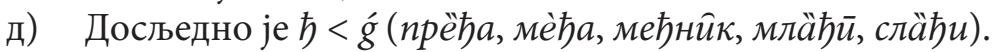

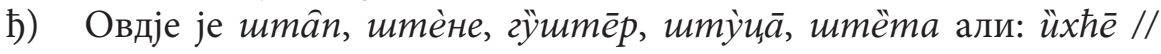

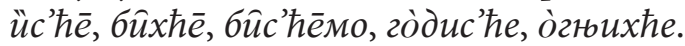

${ }^{8}$ Pavle Ivić i Slobodan Remetić, Trijebine (OLA 78). Fonološki opisi srpskohrvatskih/hrvatskosrpskih, slovenačkih i makedonskih govora obuhvaćenih Opšteslovenskim lingvističkim atlasom. - Akademija nauka i umjetnosti Bosne i Hercegovine, knj. V, Odjeljenje društvenih nauka, knj. 9, Sarajevo 1981, 561, 564. 
е) Јекавско јотовање системски је проведено једино уз $\pi$ и н (љьёса, љьёсе, љьёто, иъёме, юеемачки, али је нёко, нёкад, нёшто; облик гње́здо настао је, наравно, другим путем), те у ликовима ђё и пљёга, као и у облицима глагола хтјёти и тјёрати (хћёли // c’ћёли, по̀ћера̄j, оћерали). Иначе је увијек: бјёжи, вјётар, усмр̀дјело се, мјёсееи, излеттјело, ѝзјели, ијёпља.

ж) Ново јотовање изостаје уз лабијале (рӥбија̄ уิста, дйвјака, крӓвјаћа, комјёъье) и дентале $c$ и з (прӧсја̄к, сја̄jû се ӥзјутра). Овдје је су̀dje, али ле́ђ а, рӧђ $\bar{\kappa}$. Слушао сам само лиิхће // лйсћe, пруіће.

3) У вези са консонантизмом поменимо на крају и податак да је метатеза узела прилично широког маха (твйиа, пётеро твић $\bar{a}-$

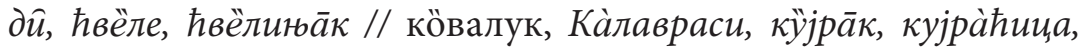
кӥјраћа̄дu НПл).

4. Од морфолошких карактеристика помињем једино ИСг имени-

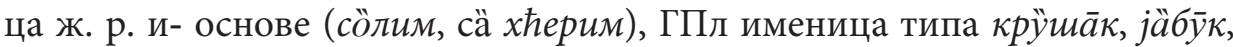

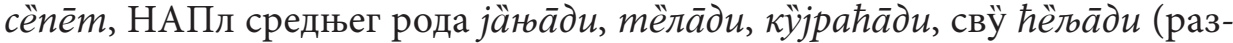
лика према генитиву обезбијеђена је акценатском опозицијом: јärь $\bar{a} \partial u$ // јања́дй //. Навешћу и петрефакте прилога времена прошлог (сјёдавщи, лёжавши, стӓвши, по̀ша̄в, не би́вши и сл.).

\section{III}

Својом општом сликом овај говор се уклапа у круг стариначких источнобосанских говора, мада он у ствари није ни прави ијекавски (због екавске замјене дугог јата) а ни шћакавски. С друге стране, иако је ријеч о изразито метанастазичком подручју и иако трећина данашњих становника Плаховића тврди да су им се преци доселили из ванбосанских крајева, говор Плаховићана ни от куд није донијет. Чак ни од Тешња ни Маглаја (и у самим Плаховићима упорно искључују могућност да се ико њихов отуда доселио), јер ова два говора раздвајају неке крупније и ситније особине (акут, судбина африката $и$ и $u, u \hbar a \bar{u}: u m a \bar{u}$ и сл.). Очито се ради о остацима једног говорног типа који је некада покривао шири простор а данас му трагове срећемо у Кладњу. Можда ће се они наћи у још којем кладањском селу, што ће детаљнија истраживања тога краја показати. У том контексту се ургентном појављује и потреба расвјетљавања говорне слике сарајевских Бјелава, а подаци којима располажем напросто подразумјевају ситуацију сличну плаховићкој и у говору бар једног дијела сребреничких Муслимана. 
И да завршимо. Откриће незамијењеног јата на широком простору сјеверозападне Србије, ијекавско-екавског говора у кладањском крају као да опомиње и потврђује да је, на жалост, још увијек актуелна Брозовићева духовита али у основи тачна оцјена из 1960. године да су наше

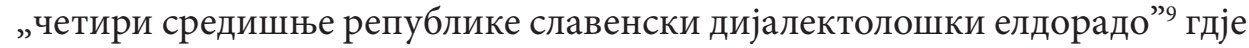
су могућа оваква и каква ли све још изненађења!

${ }^{9}$ D. Brozović, O problemu ijekavskošćakavskog (istočnobosanskog) dijalekta, 119. 